Murmurations:

Journal of

Transformative

Systemic

Practice

\title{
Editorial
}

\section{Gail Simon}

Volume 2

Issue 2

Winter 2019

\author{
Citation Link
}

If we might choose a theme for this issue, it could be "daring". In the future, perhaps it will be remembered as the issue which dared to introduce a systemic paradigm shift.

Each of the papers in this issue draws to some degree on new materialist posthuman theory which has been generating much transdisciplinary interest.

The opening paper by Leah Salter (Wales) and Gail Simon (England) introduces transmaterial worlding as a new onto-epistemology for systemic living. The paper re-frames social construction to include nonhuman material participants as important intra-active communicating partners. Examples illustrate ecosystemic worlding practices which explore how power relations influence whether our thinking is joined up or not. The closing paper by Robert van Hennik (Netherlands), proposes the importance of becoming a posthuman systemic nomad. He explains key concepts from new materialist theory and suggests systemic practitioners need to free themselves from narratives of what counts as valid to become systemic nomads and claim "validity from within". Robert's paper forms part one of an extended two part piece of writing with the second part opening the next issue of the journal.

In her paper, Dare to Play, Joanna Michopoulou (Greece), engages us in stories about what it means to play, to learn and take risks in the context of needing to go further and learn new things in and about the world. Marilena Karamatsouki (Greece) dares to speaks from deep within a therapeutic relationship against a backdrop of economic crisis to maintain ethical transparency. While there may be a degree of risk to respond openly to a client's observations about a therapist, it is also a risk to deflect attention and not honour the nature of an enquiry from a client. Paula Kennedy (England) and Monica Whyte (Ireland) decide to take a risk and organise a workshop differently in which they ask participants to dare to take up their invitation and enter an endarkened room with moving voices telling true stories about their lives. Imelda McCarthy and Jean Minogue (Ireland), perhaps use another form of daring in trusting that a fifth province will emerge through group intra-activity, a unity which transcends narratives of the individual unit or conscious logic, to enter into an onto-epistemological process of becoming one with others. 
People and places whose voices are included in these papers have also been daring. They trust their therapists, group leaders, trainers, and us as writers and readers, to honour and connect with their experiences and dare to open up enough to learn from them.

Our "M Talk" for this issue is a fascinating talk between Gwyn Daniel (England) and Justine van Lawick (Netherlands) reflecting on how families are portrayed in the theatre especially in Shakespeare's plays. They discuss how Shakespeare dared to show social change through the dramas in intimate relationships and how personal crises reflected change at a meta-level depending on power positions in society. Gwyn's book is linked to under the video.

Daring is a form of engagement, and at the same time, it requires us to let go of what we expect to happen, of who-what we think matters, of who-what we think we know. In order to dare to play and take ethical risks we need to understand the relational contexts we are acting into and out of. Each of the papers offer a theorethical description of how they connect theory and ethics (Simon 2012). In the systemic world, theory and ethics must be inseparable if we choose and discuss theories to respond appropriately for the context, not "marry" that which is familiar to us, and not let theories choose us or, indeed, be imposed on us.

Our revivals paper for this issue may be able to help us with some important challenges. Firstly, in introducing her 1993 paper on how her relationship with systemic "rules" changed over time, Desa Markovic describes the process for many trainees of moving through stages of understanding "rules" towards "positive delinquency". Secondly, Desa Markovic was writing from within the tailwind of a paradigm shifting era in systemic theory and practice. Social construction was washing through everyday systemic practice. We were starting to see human systems as linguistic systems, not simply behavioural or problematic systems. This was a massive theorethical shift for systemic practitioners. It took some giant leaps of faith and an in-depth study of some brilliant texts and conversations to discuss ethical reasons for this way of understanding and practising systemic therapy.

The point of Murmurations: Journal of Transformative Systemic Practice is to encourage systemic practitioners back into play, to experiment in practice, to know the rules but bend them ethically to suit the context; to dare to write (perhaps without yet knowing why one feels a need to write), to dare to share and learn in the moment of telling, and in hearing back from colleagues. We need to feel free to re-invent or develop systemic practice while treasuring the contributors who went before us, or alongside us, and those yet to have their voices heard. Murmurations is more than a journal. It is a platform, a theatre with new lighting which perhaps shows us back what we already know or things we do not yet know or get until people take us on a journey and tell us good stories from their own lives. Experimenting with new forms, new stitching, new materials, and voices not commonly heard is surely a systemic ethic. Let's embrace a new era in which we dare to invite ourselves into new worlding opportunities.

\section{Citation}

Simon, Gail (2019). Editorial. Murmurations: Journal of Transformative Systemic Practice, 2, 2, i-ii. https://doi.org/10.28963/2.2.1 